\title{
A rare case of endometriosis to clear cell ovarian carcinoma: a case report
}

\author{
Anaswara T. ${ }^{1}$, Prasanna Venugopalan ${ }^{1 *}$, Vidhu V. Nair ${ }^{1}$, Alfy Ann George ${ }^{2}$, I. Praseeda ${ }^{2}$
}

\begin{abstract}
${ }^{1}$ Department of Obstetrics and Gynaecology, Travancore Medical College Hospital, Kollam, Kerala, India
${ }^{2}$ Department of Pathology, Travancore Medical College Hospital, Kollam, Kerala, India
\end{abstract}

Received: 24 August 2019

Accepted: 30 September 2019

\section{*Correspondence:}

Dr. Prasanna Venugopalan,

E-mail: vidhuvnair@outlook.com

Copyright: () the author(s), publisher and licensee Medip Academy. This is an open-access article distributed under the terms of the Creative Commons Attribution Non-Commercial License, which permits unrestricted non-commercial use, distribution, and reproduction in any medium, provided the original work is properly cited.

\begin{abstract}
Clear cell carcinoma of ovary is a rare tumour with a very low incidence in pregnancy. It is attributed to develop from an existing background of endometriosis. There are very few case reports of the above combination tumours in pregnancy. It is a very aggressive tumour with a worse prognosis and low survival rate because of its peculiar chemo resistant nature. Early detection and effective treatment are the best approach. The treatment options for advanced stages are still under research.
\end{abstract}

Keywords: Aggressive, Chemo resistant, Clear cell carcinoma, Endometriosis, Low survival, Rare, Worse prognosis

\section{INTRODUCTION}

Incidence of ovarian masses detected during pregnancy is between $0.1 \%$ and $2 \% .^{1}$ Majority of them are cystic in nature and incidence of ovarian malignancy in pregnancy is between 1:10,000 and 1:50,000 with a higher prevalence for dysgerminomas and malignant teratomas. $^{2}$

Clear cell carcinomas arise from a back ground of ovarian endometriosis with an incidence of $0.8 \%$ with its occurrence in pregnancy being extremely rare. It is a subtype of epithelial ovarian cancer with a general incidence of 3.7-12.1\%. ${ }^{3}$ Majority are diagnosed at FIGO Stage I and present as a large pelvic mass with size ranging from 3 to $20 \mathrm{~cm}$. Bilaterality is rare with frequent complications like thromboembolism and hypercalcemia. ${ }^{4}$ Histologically, it is characterised by clear cells in solid/tubular or glandular pattern and hob nailing. The treatment consists of staging laparotomy followed by combination (platinum and paclitaxel) chemotherapy, but advanced stages are found to be chemo resistant. ${ }^{5}$ Therefore, the recurrence rate is found to be high and survival rate is low and as such it is a highly aggressive tumour.

\section{CASE REPORT}

A 31-year-old primi gravida at 30 weeks 4 days gestation who was a booked case in an outside hospital was referred to Travancore Medical College, Kollam as a case of IUGR, abnormal Doppler, oligohydramnios, placenta previa, breech presentation with a right adnexal cyst. On detailed enquiry into her pre conceptional and antenatal period, it was found that she conceived after ovulation induction and was a k/c/o ovarian endometriosis diagnosed with right ovarian cyst since 2013 and was advised cystectomy for the same, but was reluctant to undergo surgery. Therefore, as a part of infertility treatment she underwent multiple cycles of ovulation induction. First and second trimesters were uneventful and the scans were corresponding with an evident right 
adnexal endometriotic cyst of size $5 \times 5 \mathrm{~cm}$. At 29 weeks on her growth scan she was detected to have placenta previa, with growth corresponding to 27 weeks and AFI of 3-4 cm. So, she was admitted and was given supportive treatment with intravenous fluids for correction of oligohydramnios, betamethasone injection for foetal lung maturity repeat scan after 5 days also showed AFI of 3-4 cm and was referred to our hospital.

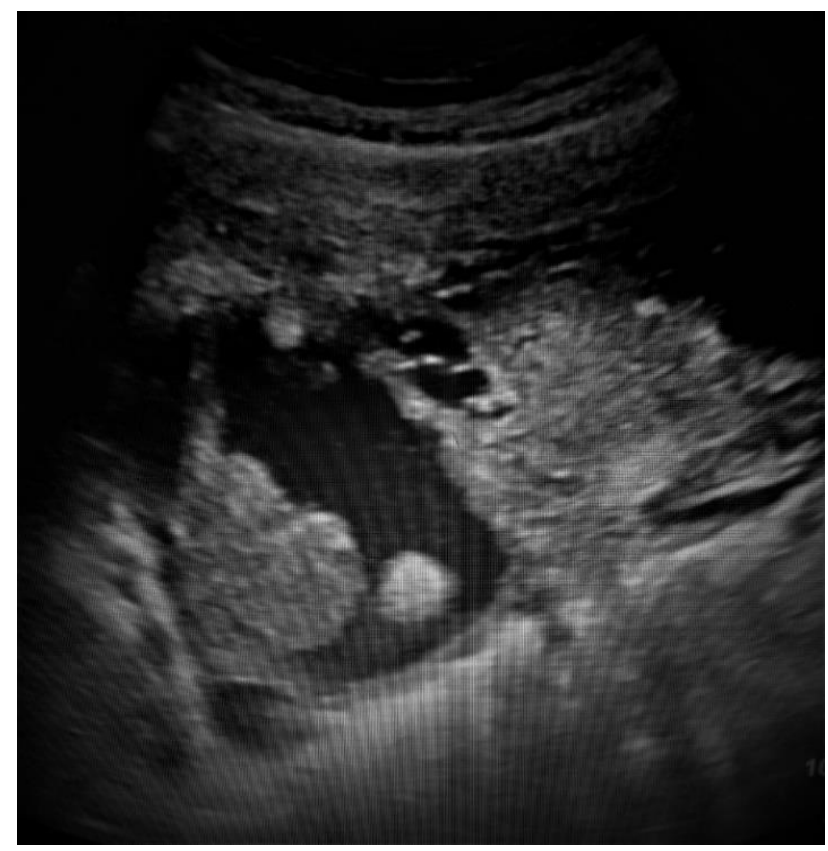

Figure 1: USG finding showing complex right adnexal cystic lesion measuring $8.5 \times 6 \mathrm{~cm}$ containing solid components and mural nodules.

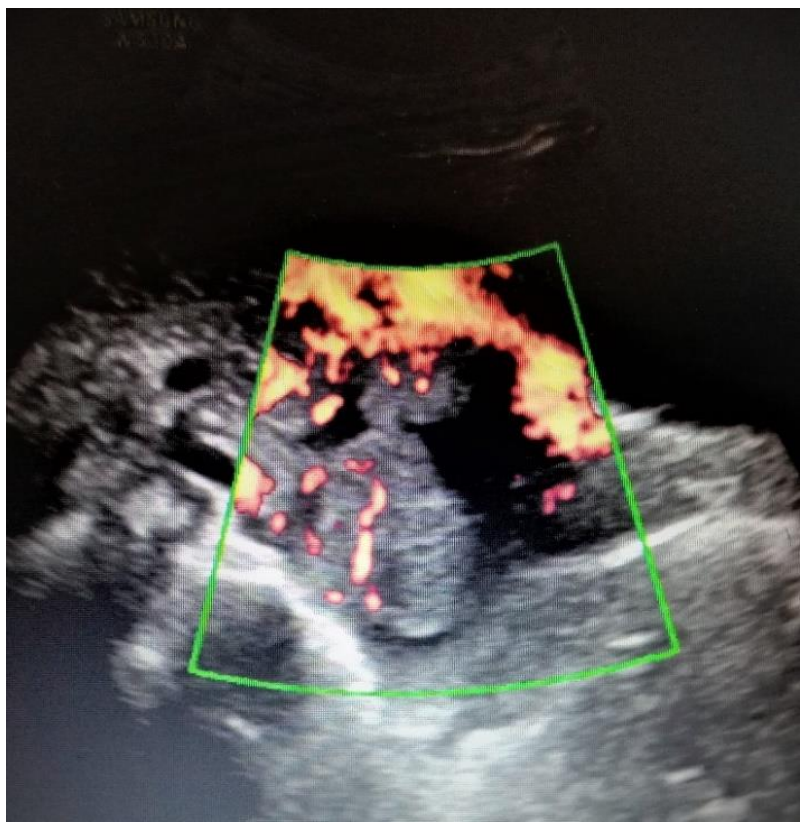

Figure 2: USG finding showing complex adnexal cystic lesion containing solid components showing peripheral vascularity.

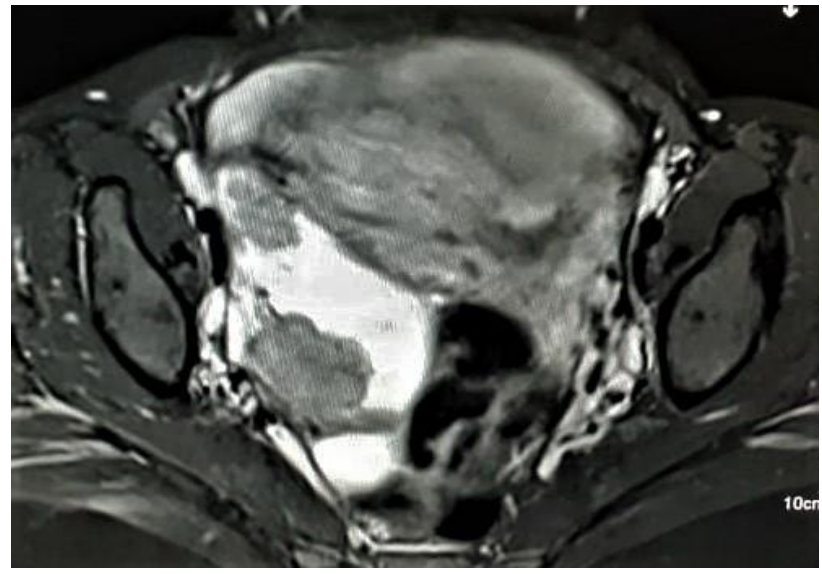

Figure 3: MRI pelvis: axial stir showing complex cystic lesion $8 \times 8 \mathrm{~cm}$ with solid component.

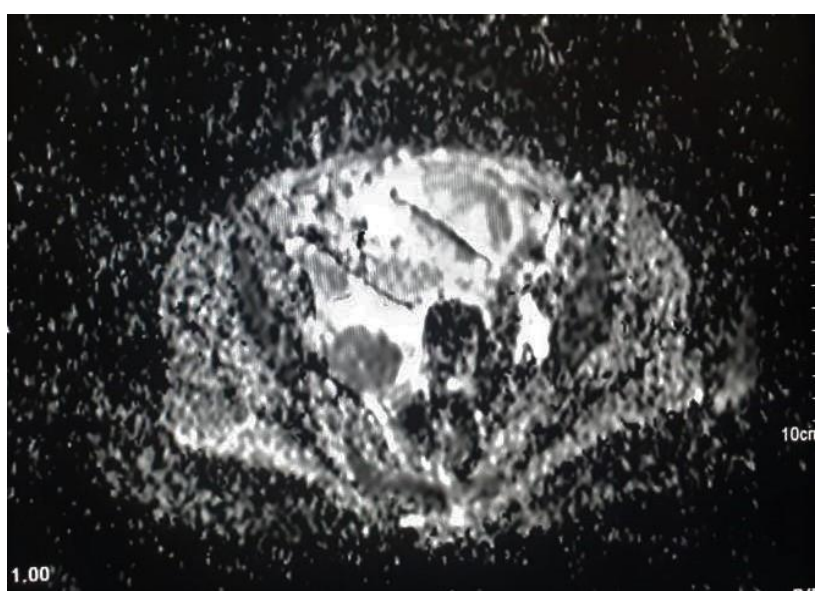

Figure 4: MRI pelvis - diffusion weighted images with ADC map showing restricted diffusion.

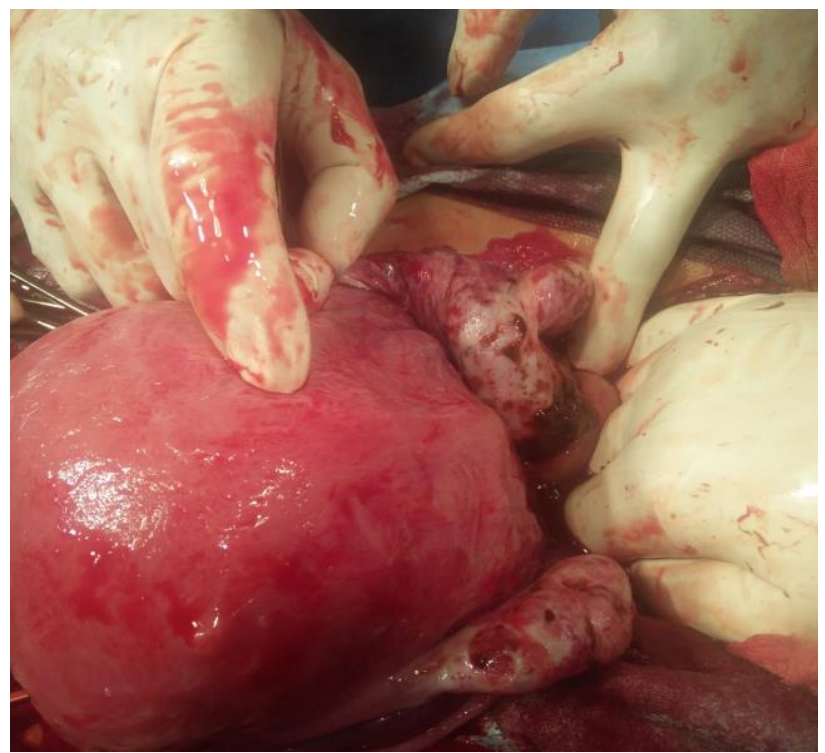

Figure 5: Intra op finding - right ovarian endometriotic cyst $6 \times 6 \mathrm{~cm}$ partly solid and cystic in nature with cyst wall ruptured. 
On obstetric USG and doppler assessment from our hospital at 30 weeks 4 days showed IUGR of 2 weeks disparity, high resistance flow in umbilical artery and a large cystic area in right adnexa measuring $8.5 \times 6 \mathrm{~cm}$ containing focal solid areas (Figure 1) with minimal peripheral vascularity (Figure 2) and oligo hydramnios (AFI: 3-4 cm). MRI done showed complex right adnexal cyst measuring $8 \times 8 \mathrm{~cm}$ with eccentric smooth solid components (Figure 3). Solid areas showing diffusion restriction with low ADC values (Figure 4). Tumour markers were normal. In view of her complaints of decreased foetal movements and non-reassuring NST, she was taken up for Emergency LSCS. A preterm live male baby of weight $1.315 \mathrm{~kg}$ was delivered as breech with good cry.

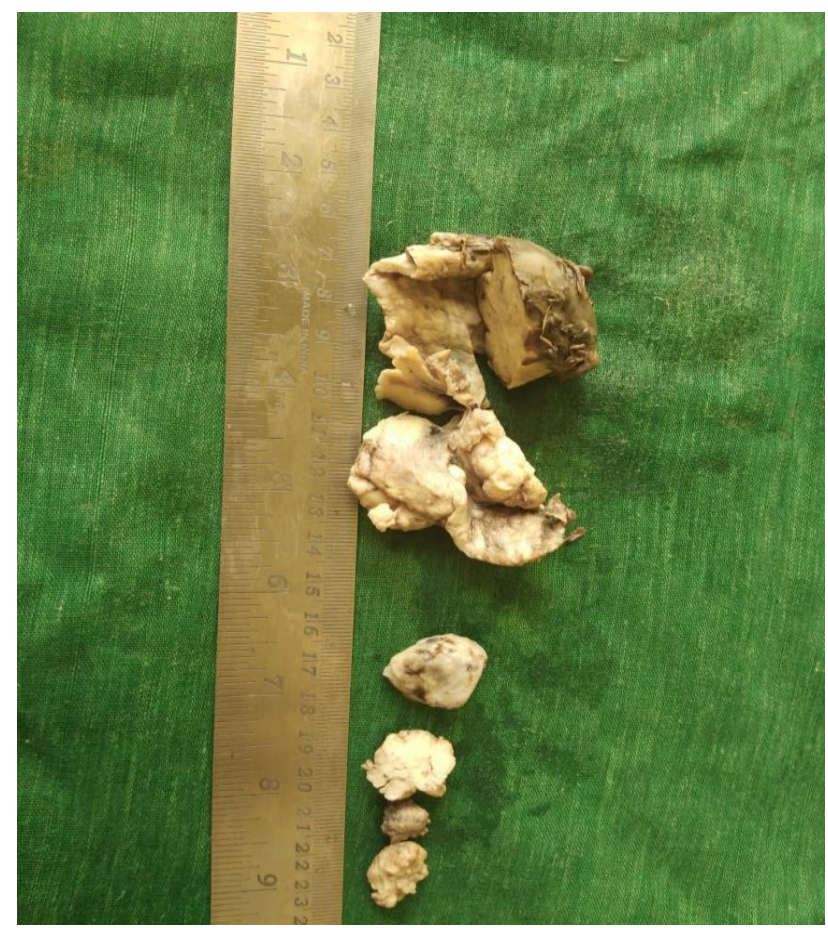

Figure 6: Gross specimen showed fragments of ovarian mass showing solid and cystic neoplasm, cyst wall is thick, yellowish white with fleshy nodules and solid papillary areas measuring $3.5 \times 3.5 \mathrm{~cm}$ with tiny papillary projections.

Intra op findings were right ovarian endometriotic cyst $6 \times 6 \mathrm{~cm}$ partly solid and cystic in nature with cyst wall ruptured and sealed off by omentum (Figure 5). Multiple endometriotic deposits on the posterior surface of uterus and peritoneum. No free fluid seen, peritoneal washings were taken and right salphingo-oophorectomy was done. Specimens were sent for cytology and histopathology. Intra op and post op periods were uneventful. Patient was discharged on $5^{\text {th }}$ post op day. Histopathology report came as clear cell carcinoma of right ovary and cytology was negative. Gross specimen showed fragments of ovarian mass showing solid and cystic neoplasm, cyst wall is thick, yellowish white with fleshy nodules and solid papillary areas measuring $3.5 \times 3.5 \mathrm{~cm}$ with tiny papillary projections (Figure 6). Microscopy showing neoplasm composed of tubule cystic spaces lined by tumour cells with clear cytoplasm, high grade nuclear features and nuclear hob nailing. Stroma shows dense lymphoplasmacytic infiltrate (Figure 7). Adjacent endometriotic foci seen. It was staged as FIGO stage Ic2 since tumour was limited to one ovary and capsule was ruptured before surgery. After the histopathology report she underwent a staging laparotomy followed by total abdominal hysterectomy with bilateral salpingo oophorectomy and at present is on third cycle of postoperative adjuvant chemotherapy with carboplatin and paclitaxel.

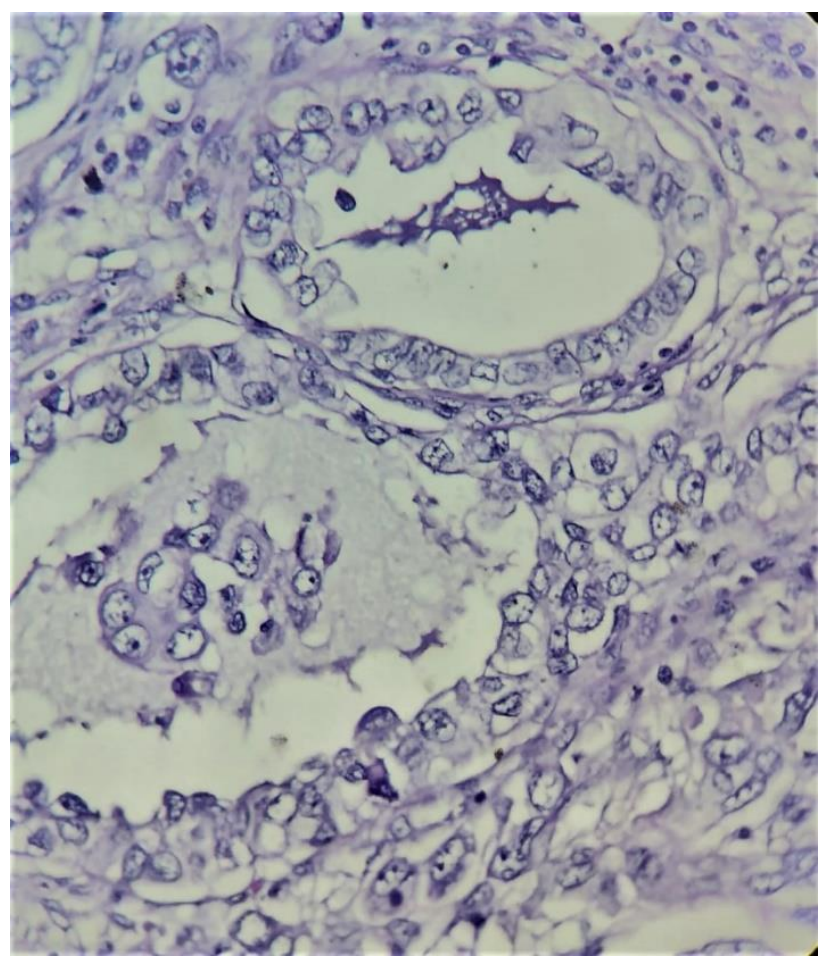

Figure 7: Microscopy showing neoplasm composed of tubule cystic spaces lined by tumour cells with clear cytoplasm, high grade nuclear features and nuclear hob nailing. Stroma shows dense lymphoplasmacytic infiltrate.

\section{DISCUSSION}

Long standing endometriosis can turn into either clear cell carcinoma or endometrioid carcinoma of ovary with an incidence of $0.8 \%$. Clear cell carcinoma is a subtype of epithelial ovarian cancers. Nishida et al reported that malignant change occurred in $0.7 \%$ of ovarian endometriosis. ${ }^{6}$ Early diagnosis at an early stage can improve the survival rate. MRI during pregnancy is an important modality for the diagnosis.

The staging for clear cell carcinoma follows the same FIGO 2018 staging of ovarian, fallopian tube and peritoneal cancers which is a surgical staging. The origin of these tumors is thought to be from the distal end of 
fallopian tube. Ovarian epithelial tumours are believed to originate from cortical inclusions of mullerian epithelium or from endometriosis.

The incidence of ovarian clear cell carcinomas is estimated to be less than $5 \%$ and majority present at stage I of the disease. Behbakht et al, in his study found $60 \%$ patients in stage I and $11 \%$ in stage II disease. ${ }^{7}$ Nishino et al reported out of 20 patients, $90 \%$ were in stage I/II with
12 in stage Ic, one in IIa and five in IIc. ${ }^{8}$ Kennedy et al reported $60 \%$ of cases were in stage I/II. ${ }^{9}$ Skirnisdottir et al, found that $64 \%$ patients belong to stage Ic and IIc. ${ }^{10}$ Similarly, Jennison et al in his study reported $59 \%$ patients in early stage of ovarian clear cell carcinomas. ${ }^{11}$

Besides our case there were 8 reported cases of pregnancy associated ovarian clear cell carcinoma which are as follows:

Table 1: Different cases of pregnancy associated ovarian clear cell carcinoma.

\begin{tabular}{|c|c|c|c|c|c|c|c|c|}
\hline No. & Age & $\begin{array}{l}\text { Presenting } \\
\text { symptom }\end{array}$ & $\begin{array}{l}\text { Size } \\
(\mathrm{cm})\end{array}$ & Surgical treatment & Chemotherapy & $\begin{array}{l}\text { FIGO } \\
\text { stage }\end{array}$ & $\begin{array}{l}\text { Maternal } \\
\text { outcome }\end{array}$ & Author et al \\
\hline 1 & 31 & Asymptomatic & 14 & RSO at 10 weeks & No & Ia & Normal & Kobayashi $^{12}$ \\
\hline 2 & 33 & Asymptomatic & 6.5 & $\begin{array}{l}\text { Staging lap TAH, BSO } \\
\text { at } 13 \text { weeks }\end{array}$ & Yes & Ic & Dead & Sugiyama $^{13}$ \\
\hline 3 & 31 & $\begin{array}{l}\text { Abdominal } \\
\text { pain }\end{array}$ & 7 & $\begin{array}{l}\text { CS followed by staging } \\
\text { lap at } 33 \text { weeks }\end{array}$ & Yes & IIa & Normal & Nagano $^{14}$ \\
\hline 4 & 28 & Asymptomatic & 6.5 & $\begin{array}{l}\text { CS and RSO at } 37 \\
\text { weeks }\end{array}$ & No & Ia & Normal & Satoh $^{15}$ \\
\hline 5 & 37 & Asymptomatic & 6 & $\begin{array}{l}\text { CS and staging lap at } \\
34 \text { weeks }\end{array}$ & No & Ic & Normal & Makrydimas $^{16}$ \\
\hline 6 & 35 & Asymptomatic & 13.8 & $\begin{array}{l}\text { CS and LSO at } \\
\text { 36weeks }\end{array}$ & Yes & Ic & Normal & Hwang ${ }^{17}$ \\
\hline 7 & 41 & Asymptomatic & 10 & RSO at 10 weeks & No & Ic & Dead & Matsui $^{18}$ \\
\hline 8 & 28 & Asymptomatic & 10 & RSO at 9 weeks & No & IIc & Normal & Shin $^{19}$ \\
\hline
\end{tabular}

The definite diagnosis of ovarian clear cell carcinoma can be made by histological analysis of the ovarian cyst obtained by either frozen section or routine post op histopathology showing the characteristic clear cells and hob nailing pattern (Figure 7).

IHC shows CK7 positivity, CD 20 negativity, ER /PR and WT1 negativity. For preoperative diagnosis the imaging modalities may be helpful which can indicate a malignant change in ovarian cyst - USG and MRI (Figure 1, Figure 3). The presence of solid areas, complex nature, bilaterality, increased vascularity with low RI, papillary pattern, multilocularity and ascites may be suggestive of malignant nature. Tumour markers for epithelial ovarian cancers namely CA -125 , CEA will be elevated but is of limited value in pregnancy. Normally the tumour markers peak in first trimester and returns to normal in second trimester.

The prognosis mainly depends upon the stage of cancer at the time of diagnosis, histological type, histological grade and the maximum diameter of residual disease after cyto reductive surgery. Stage I/II disease and low-grade disease has good prognosis. The foetal prognosis can be sub optimal due to intrauterine hemodynamic alterations causing reduced uterine and placental blood flow and immunological changes leading to the development of IUGR and stillbirth.
The treatment of ovarian clear cell carcinoma is similar to other malignant epithelial ovarian tumours with stagebased treatment regime. Stage $\mathrm{I}$ a/b grade 1 and 2 Surgical staging followed by extra facial hysterectomy with BSO. For stage I a/b grade 3, stage I c and stage II surgical staging with adjuvant chemotherapy (3-6 cycles of carboplatin and paclitaxel). For advanced stages- III and IV primary cyto reductive surgery followed by adjuvant chemotherapy or neo adjuvant chemotherapy followed by interval cyto reduction is done as per EORTC and CHORUS trials. However, in pregnancy surgical treatment result in increased risk of miscarriage in first trimester and preterm labour in third trimester. Hence, second trimester is considered ideal for surgery. Chemotherapy in pregnancy in contraindicated in view of embryo toxicity, congenital malformations such as gastroschises, skeletal anomalies, IUGR, reduced brain growth, dilatation of cerebral ventricles and intra uterine death associated with carboplatin.

The survival rate following surgery for ovarian clear cell carcinoma is higher for stage I and II. This is in accordance with Kennedy et al where survival rates for stage I and II were similar to other EOC while stage III $(26 \%)$ and IV $(0 \%)$ have a dismal outcome. ${ }^{9}$ Sugiyama et al reported a low response rate $(11.1 \%)$ with platinum based chemotherapy. ${ }^{13}$ Goff et al reported that patients with stage III had a shorter survival rate. ${ }^{20}$ The poor 
response rates to platinum based regimens is attributed to chemo resistance developed as a result of decreased drug accumulation, increased detoxification, low proliferation rate of tumour and increase in DNA repair. No other chemotherapeutic agent is found to be effective in clinical studies.

\section{CONCLUSION}

Due to the low incidence rate of ovarian clear cell carcinoma, it is treated similar to other EOC. Chemo resistance is observed in advanced stages and therefore advanced stages have guarded prognosis with very low survival rates. Maternal outcome in advanced stages is very dismal.

\section{Funding: No funding sources Conflict of interest: None declared Ethical approval: Not required}

\section{REFERENCES}

1. Otton G, Higgins S, Phillips KA, Quinn M. A case of early-stage epithelial ovarian cancer in pregnancy. Int J Gynecol Cancer. 2001;11(5):413-7.

2. Sayar H, Lhomme C, Verschraegen CF. Malignant adnexal masses in pregnancy. Obstet Gynecol Clin. 2005;32(4):569-93.

3. Crozier MA, Copeland LJ, Silva EG, Gershenson DM, Stringer CA. Clear cell carcinoma of the ovary: a study of 59 cases. Gynecol Oncol. 1989;35(2):199-203.

4. Recio FO, Piver MS, Hempling RE, Driscoll DL. Lack of improved survival plus increase in thromboembolic complications in patients with clear cell carcinoma of the ovary treated with platinum versus nonplatinumbased chemotherapy. Cancer: Interdiscip Int J Am Cancer Soci. 1996;78(10):2157-63.

5. Pectasides D, Pectasides E, Psyrri A, Economopoulos T. Treatment issues in clear cell carcinoma of the ovary: a different entity? The Oncol. 2006;11(10):1089-94.

6. Nishida $M$, Watanabe $K$, Sato $N$, Ichikawa $Y$. Malignant transformation of ovarian endometriosis. Gynecol Obstet Invest. 2000;50:18.

7. Behbakht K, Randall TC, Benjamin I, Morgan MA, King S, Rubin SC. Clinical characteristics of clear cell carcinoma of the ovary. Gynecol Oncol. 1998;70(2):255-8.

8. Nishino K, Aoki Y, Amikura T, Obata H, Sekine M, Yahata T, Fujita K, Tanaka K. Irinotecan hydrochloride (CPT-11) and mitomycin $\mathrm{C}$ as the first line chemotherapy for ovarian clear cell adenocarcinoma. Gynecol Oncol. 2005;97(3):893-7.

9. Kennedy AW, Biscotti CV, Hart WR, Webster KD. Ovarian clear cell adenocarcinoma. Gynecol Oncol. 1989;32(3):342-9.
10. Skírnisdóttir I, Seidal T, Karlsson MG, Sorbe B. Clinical and biological characteristics of clear cell carcinomas of the ovary in FIGO stages I-II. Int $\mathbf{J}$ Oncol. 2005;26(1):177-83.

11. Jenison EL, Montag AG, Griffiths CT, Welch WR, Lavin PT, Greer J, et al. Clear cell adenocarcinoma of the ovary: a clinical analysis and comparison with serous carcinoma. Gynecol Oncol. 1989;32(1):65-71.

12. Kobayashi F, Monma C, Nanbu K, Konishi I, Sagawa $\mathrm{N}$, Mori $\mathrm{T}$. Rapid growth of an ovarian clear cell carcinoma expressing $\mathrm{LH} / \mathrm{hCG}$ receptor arising from endometriosis during early pregnancy. Gynecol Oncol. 1996;62(2):309-13.

13. Sugiyama T, Nishida T, Kataoka A, Okura N, Iwanaga S, Yakushiji M. A pregnant woman with clear cell adenocarcinoma of the ovary arising from endometriosis and with benign and borderline adenofibroma of the clear cell and endometrioid types. Eu J Obstet Gynecol Repro Biol. 1997;72(1):47-50.

14. Nagano H, Sawai H, Oomoto H. A case of pregnancy associated clear cell carcinoma, making it difficult to diagnose (in Japanese). Chugoku Shikoku Dist J Jpn Soc Obstet Gynecol. 1999;47:231-2.

15. Satoh K, Matsushima $T$, Tsukada K, Konishi $H$, Ishihara $\mathrm{K}$, et al. A case of pregnancy associated with clear cell carcinoma (in Japanese). Kanto J Obstet Gynecol. 2000;37:295.

16. Makrydimas G, Sotiriadis A, Paraskevaidis E, Pavlidis $\mathrm{N}$, Agnantis N, et al. Clear cell ovarian carcinoma in a pregnant woman with a history of infertility, endometriosis and unsuccessful IVF treatment. Eur J Gynaecol Oncol. 2003;24:438-41.

17. Hwang CS, Park SY, Yu SH, Park JY, Park CT. Hypercalcemia induced by ovarian clear cell carcinoma producing all transcriptional variants of parathyroid hormone-related peptide gene during pregnancy. Gynecol Oncol. 2006;103:740-4.

18. Matsui H, Saito M, Tanuma Y. A case of pregnancy associated with ovarian clear cell carcinoma. Tokyo $\mathbf{J}$ Obstet Gynecol. 2010;59:389-92.

19. Shin JW, Ku CH, Lee HH, Kim SY. Clear cell carcinoma of ovary cervix affecting the women with early pregnancy. Acta Obstet Gynecol Jpn. 2012;64:900.

20. Goff BA, de la Cuesta RS, Muntz HG, Fleischhacker D, Ek M, Rice LW, et al. Clear cell carcinoma of the ovary: a distinct histologic type with poor prognosis and resistance to platinum-based chemotherapy in stage III disease. Gynecol Oncol. 1996;60(3):412-7.

Cite this article as: Anaswara T, Venugopalan $\mathrm{P}$, Nair VV, George AN, Praseeda I. A rare case of endometriosis to clear cell ovarian carcinoma: a case report. Int J Reprod Contracept Obstet Gynecol 2019;8:4585-9. 